Article

\title{
Berlin's Manifold Strategies Towards Commercial and Industrial Spaces: The Different Cases of Zukunftsorte
}

\author{
Lech Suwala ${ }^{1,2, *}$, Robert Kitzmann ${ }^{2}$ and Elmar Kulke ${ }^{2}$ \\ ${ }^{1}$ Department of Urban and Regional Planning, Technical University of Berlin, Germany; E-Mail: lech.suwala@tu-berlin.de \\ 2 Department of Geography, Humboldt University of Berlin, Germany; E-Mails: lech.suwala@geo.hu-berlin.de (L.S.), \\ robert.kitzmann@geo.hu-berlin.de (R.K.), elmar.kulke@geo.hu-berlin.de (E.K.) \\ * Corresponding author
}

Submitted: 28 February 2021 | Accepted: 20 May 2021 | Published: 23 September 2021

\begin{abstract}
Despite being the third largest industrial agglomeration in the world before World War II, Berlin was faced with an economic void after the partition and reunification of the city with many abandoned and alienated commercial and industrial spaces in a compact urban fabric. What has happened with this commercial and industrial heritage over the last 30 years? The main rationale behind this article is to show how Berlin planned and developed some of these spaces through the Zukunftsorte strategy by preserving its historical sites and modernizing its commercial and industrial base. As part of this undertaking, the article combines insights from urban planning and regional innovation studies. Methodologically, a two-step approach is applied: First, the article conducts an analysis of fundamental planning frameworks and technology/innovation policy trajectories with regard to commercial and industrial spaces; second, a multiple-case study analysis of selected Zukunftsorte (Adlershof, Marzahn, Schöneberg, Siemensstadt) is carried out to test whether and to what extent those spaces are supported by planning frameworks and exhibit components of what we coined territorial ecosystem models. The data compiled stems from 15 years of work engaging in various planning and policy steering committees, individual or joint research projects, personal interviews with relevant stakeholders, and regular field observations. The findings suggest that Berlin's strategies towards commercial and industrial spaces need to integrate highly contextual approaches since size, progress, operation, means, and timelines of Zukunftsorte vary substantially. Whereas Adlershof is a well-functioning network of business, academia, planners, and policymakers with preliminary attempts to embed those stakeholders in residential neighborhoods and the European Energy Forum in Schöneberg-which can be described as a miniature living lab of Adlershof-the other investigated Zukunftsorte do not yet deserve to carry this name.
\end{abstract}

\section{Keywords}

Berlin; commercial and industrial planning; technology and innovation policies; territorial ecosystem models; territorial innovation models; Zukunftsorte strategy

\section{Issue}

This article is part of the issue "Future Commercial and Industrial Areas" edited by Angela Million (TU Berlin, Germany) and Felix Bentlin (TU Berlin, Germany).

(C) 2021 by the authors; licensee Cogitatio (Lisbon, Portugal). This article is licensed under a Creative Commons Attribution 4.0 International License (CC BY).

\section{Introduction}

Urban commercial and industrial spaces undergo transformations in manifold ways: as abandoned brownfields, residential neighborhoods, shopping centers, revitalized old industrial sites, urban areas for events and spectacles, milieus for creativity and innovation, or modern living labs (Kitzmann \& Suwala, 2018). Once the third largest industrial agglomeration in the world, Berlin looks back on a long history of such spaces. The city's unique past of being devastated by the World War II, partitioned during the Cold War, deprived of suburbanization processes 
until 1990, and hollowed out shortly thereafter left behind many empty commercial and industrial spaces inside a compact urban fabric (Ellger, 1992; Kulke, 2003). Against this background, the purpose of this article is to shed light on how Berlin planned and developed some of these spaces using the Zukunftsorte strategy to preserve its historical sites and modernize its commercial and industrial base. As part of this undertaking, we combine insights from urban planning and regional innovation studies. This distinctive theoretical perspective makes it possible to analyze not only planning frameworks to preserve and develop such areas, but also technology and innovation initiatives to revitalize and modernize them. In doing so, we are able to broaden the view for both subdisciplines and contribute to debates on interdepartmental and integrative planning, as well as territorial innovation platforms and ecosystems. Methodologically, we apply a two-step approach: First, we analyze the planning frameworks and innovation/technology initiatives with regard to commercial and industrial spaces to demonstrate that the Zukunftsorte strategy encompasses policies from both fields; second, using case studies with selected Zukunftsorte, we test whether and how those localities align with modern planning paradigms and the other building blocks of territorial ecosystem models (TEM) mentioned above. The data compiled stems from 15 years of work engaging in various planning and policy steering committees, individual and joint research projects, personal interviews with relevant stakeholders, and regular field observations from excursions and walks for international and domestic expert and student groups to all Zukunftsorte locations discussed in the article. The article is structured as follows: Section 2 introduces theoretical discourses around commercial and industrial spaces from an urban planning and regional innovation studies perspective, as well as the empirical origins of the Zukunftsorte strategy by reconstructing pertinent planning and policy framework trajectories since 1990 in Berlin; Section 3 examines four examples of Zukunftsorte (Adlershof, CleanTech Marzahn [CTM], European Energy Forum [EUREF] Campus Berlin, Siemensstadt 2.0) to assess whether and to what extent modern planning imperatives and other theoretical building blocks of TEM have already been implemented; Section 4 summarizes the main results and pinpoints the value added for ongoing theoretical and empirical discourses.

\section{Theoretical Accounts and Berlin's Trajectories Toward the Zukunftsorte Strategy}

The article applies a twofold perspective on Berlin's strategies towards new commercial and industrial spaces based on urban planning and regional innovation studies. For this purpose, we briefly outline theoretical accounts from both perspectives (2.1), show development trajectories of pertinent planning frameworks and policy initiatives since 1990 (2.2), and amalgamate and pinpoint these theories, frameworks, and initiatives based on the Zukunftsorte strategy in Berlin (2.3).

\subsection{From Triple-Helix-Driven Commercial and Industrial Spaces to Integrated Regional Ecosystems}

Let us start with some introductory remarks about urban planning and urban governance related to commercial and industrial spaces in Germany and their idiosyncrasies in Berlin. Germany is a federal state with governmental and planning tasks split up between the federal government (Bund), states (Länder), and municipalities (Kommunen). Berlin is both a state and a municipality (called Bezirke in this case). In line with the principle of subsidiary, the right of municipal self-administration is constitutionally guaranteed as long as realms of extraordinary urban interest for the entire city are not concerned (e.g., Flächennutzungsplanung, i.e., preparatory land-use planning [LUP], or Stadtentwicklungspläne, i.e., urban development plans [UDP]). This right comprises compulsory (e.g., Bauleitplanung, i.e., communal landuse planning [CLUP]) and voluntary self-government tasks (e.g., communal business development). Apart from the legal responsibilities at different governmental levels, a differentiation can be made based on formal (e.g., LUP) and informal governance and planning tools (e.g., UDP). This repertoire of tasks and tools is legally underlined by pertinent sections of the Federal Land Utilization Ordinance (BauNVO, Sections 8-9; Federal Ministry of Justice and Consumer Protection, 2021, pp. 7-8) and specified by sectoral UDPs (UDP Economy) with regard to industrial and commercial spaces. For a long time, the main rationales behind these formal planning frameworks were to preserve existing and develop new spaces either by maintaining a certain commercial and industrial base (e.g., reutilizing brownfields, developing, and operating commercial yards) or by modernizing and renewing this commercial and industrial base (e.g., establishing technology and business incubators, start-up infrastructure). The modernization of the commercial and industrial base and the respective areas were also accompanied by a wave of technology and innovation policies based on so-called territorial innovation models (TIM; e.g., clusters, innovative milieus, new industrial spaces) in the 1980s and 1990s (Moulaert \& Sekia, 2003, pp. 291-294). The main idea behind TIM was to co-locate companies from related industries along economic value chains (business) and stakeholders from academia and government (altogether triple helix) on these commercial and industrial premises in spatial proximity. At the same time, the purpose was to connect them in order to generate an endemic and implicit innovation and knowledge base for the (inter)national competitiveness of these territorial entities (Brinkhoff et al., 2012, pp. 122-123).

The increasingly blurred boundaries between the above-mentioned stakeholders of the triple helix, the participation of civic society and the environmental 
concerns (fourth and fifth helix) call for novel, holistic, and more flexible planning frameworks, and technology/innovation policies (Brinkhoff \& Kitzmann, 2014, pp. 268-275; König et al., 2020, pp. 9-10). With regard to planning frameworks, both an established section of the Federal Land Utilization Ordinance on specially designated areas (Sondergebiete; see BauNVO, Section 11 in Federal Ministry of Justice and Consumer Protection, 2021 , p. 9) and a new building law category designated as urban areas (Urbanes Gebiet; see BauNVO, Section 6a in Federal Ministry of Justice and Consumer Protection, 2021 , p. 6) within this framework allow for a greater multiplicity of uses (Brandt et al., 2017, pp. 45-46). In specially designated areas, custom industrial, academic, or residential utilizations patterns can be determined (see Section 3.1). Urban areas are intended to create mixeduse zones with short distances between residence, work, education, culture, and leisure. With regard to technology/innovation policies, a second wave of initiatives, which we coin as TEM, can be observed. TEM can be understood as integrated regional ecosystems (also called regional platforms or open regions) fueled by various types of innovation (e.g., social, cultural) transforming TIMs into innovative, viable, and vibrant urban areas as a result of the participation of civic society and environmental concerns (fourth and fifth helix) legally secured by binding planning laws and guiding planning frameworks (Schmidt et al., 2018, pp. 190-193; Suwala \& Micek, 2018, pp. 354-355). This in turn requires integrated and interdepartmental planning measures and efforts for economic land (Wirtschaftsflächenkonzepte) well beyond the narrow borders of commercial and industrial logics, or more generally as places for work (Orte der Arbeit; Wagner-Endres et al., 2018, pp. 24-25). Here, knowledge as the dominating production factor alters locational requirements and disrupts production logics with great potentials driven by technological advancement or re-urbanization of production (e.g., floor space efficiency, multifunctional buildings, and vertical production), but these developments also have to cope with manifold new problems (e.g., scarce areas, land-use conflicts, displacement of low-yield uses; see Henckel et al., 1986; Wagner-Endres et al., 2018).

Given this combined theoretical framework of an extended understanding of TIM underlined by planning frameworks and resulting in TEM, we will consider Berlin's Zukunftsorte as a blueprint for the future development of commercial and industrial areas-or, in short, as promising places to live and work-and test whether selected locations already fulfill theoretical prerequisites. While doing so, we will focus on the four helices of academia (university), business (enterprises), government (policies), and civic society (housing) and also consider how these locations are supported by planning frameworks (a largely neglected dimension of the government helix; see Section 3). Before investigating this, we will provide additional background information on Berlin's planning and policy frameworks for commer- cial and industrial spaces since 1990 in general and in conjunction with the Zukunftsorte strategy in particular.

\subsection{Trajectories Toward Zukunftsorte}

Despite its legacy as the world's third largest industrial agglomeration (mainly electrical industry, heavy machinery, clothing industry) and its renowned name of Elektropolis before the World War II, two caesuras in the second half of the 20th century (World War II, 1939-1945, and the division of Berlin, 1949, 1961-1989) erased this industrial legacy and forced Berlin to start anew (Bähr, 2001; Kulke, 2003). In 1990, Berlin was economically hollowed out as most headquarters of leading enterprises have been relocated to West-Germany and only low-tech highly subsided industrial enterprises remained in the west part of the city (securing employment and strategic provision). In the east part of the city, state-owned industrial combines (Volkseigene Kombinate) were not competitive and lost their markets due to the dissolution of the Council for Mutual Economic Assistance (Rat für gegenseitige Wirtschaftshilfe; Der Regierende Bürgermeister von Berlin, 2000; Kulke \& Suwala, 2015). In addition, Berlin still exhibited the urban characteristics of a Fordist city-high density of land use, compact urban fabric with a mixture of various functions (housing, industrial, commercial)-and had to find new ways to revitalize its commercial and industrial spaces (mostly dormant or abandoned brownfields; Ellger, 1992, pp. 42-43). What has happened since then? Figure 1 shows the most important planning frameworks and innovation/technology policy initiatives in Berlin from the last three decades and illustrates two main trajectories around and toward the Zukunftsorte strategy. We use these trajectories for a thorough analysis of whether those documents align with theoretical models and planning imperatives outlined above (see Section 2.1). It is important to mention that the enforcement and implementation of those frameworks and initiatives depend on the overall political power constellation, social movements, and economic or fiscal situation within the city. Since we stem from the fields of economic geography and regional economics, we predominantly draw connections to economic circumstances where applicable. There are selected events from before 1990 that also need to be outlined in order to understand the whole story. With the exception of the 1994 preparatory LUP, all other city-wide planning frameworks, and in particular pertinent UDPs and technology/innovation policies, have a guiding but not a binding character. The preparatory LUP results in binding CLUPs flanked by voluntary local business development policies at a municipal level (see Section 3).

From a retrospective standpoint, pertinent planning frameworks dealing with commercial and industrial areas string together like pearls on a necklace; grounded on experiences made within the UDP Commerce 


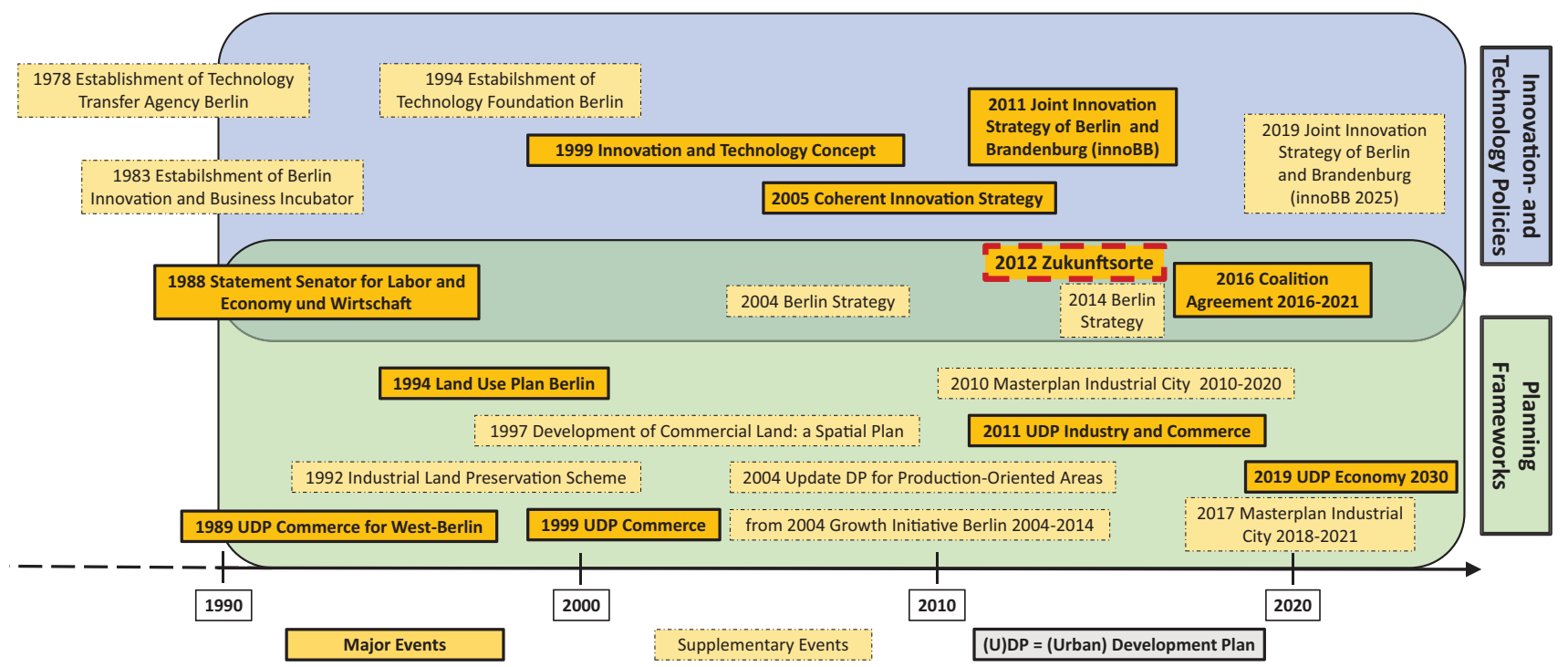

Figure 1. Planning frameworks and technology/innovation policy initiatives for commercial and industrial spaces in Berlin.

(Gewerbe) for West Berlin in 1989 and reliability in planning derived from the legally binding preparatory LUP in 1994, the Berlin administration developed revised plans (UDP Commerce in 1999, UDP Industry and Commerce in 2011, UDP Economy in 2019) roughly every ten years with updates in between. Two aspects become clear based solely on the designation and the scope of the plans. First, the separation between commerce and industry that prevailed until 2010 has been suspended, conceived jointly and now even merged under the heading "economy." For this to take place, former collateral schemes dealing with particular tasks and sectors of industry and/or commerce (e.g., industrial land preservation scheme [Industrieflächensicherungskonzept], development concept for production-oriented areas [Entwicklungskonzept für den produktionsgeprägten Bereich]) were subsumed. The "economic" UDPs were embedded in manifold further documents evidencing a broader and integrated understanding of planning and a more transparent development and participation process. They are directly referred upon in the 2004 and 2014 Berlin Strategy (updated in subsequent years) and coordinated with other UDPs (transport, mobility, retail, housing); moreover, they are also taken into account within the Industrial City Master Plan and its successors, compiled and approved by multiple stakeholders (administration, business, society; e.g., Senate Administration for Urban Development, 2004, pp. 47-48, 2011, pp. 6, 13; Senate Administration for Urban Development and Housing, 2020a, pp. 12-13, 24-25). Second, both the depiction and development of the diverse spatial and technological landscapes (Räumliche Entwicklungsmodelle) for Berlin's commercial and industrial spaces went far beyond the mere description of those spaces in the planning frameworks. Targeted fields of action and measures (e.g., acceleration of building permit procedures, customized land parceling, operating management structures for location marketing) were formulated. They qualified and profiled entire urban areas, selected locations, and unique plots through spatial and industrial priorities. At the same time, districts were called upon to define context-specific concepts for economic areas (Wirtschaftsflächenkonzepte; Senate Administration for Economy and Businesses, 1999; Senate Administration for Urban Development, 2011, pp. 13-14; Senate Administration for Urban Development and Housing, 2020a, pp. 12, 52).

The trajectory of innovation/technology policies was by far not so straightforward. Although West Berlin was among the pioneers in setting up a technology transfer agency (Technologievermittlungsagentur) in 1978 and the first innovation and business incubator in Germany (Berliner Innovations- und Gründerzentrum) in 1983, technology-oriented policies were financially overshadowed by the Berlin Subsidy Act (Berlinförderungsgesetz). Whereas only 46 million Deutsche Marks were allocated to West Berlin's technology/innovation policies (e.g., start-up advice, technology transfer and information) in 1987, nine billion Deutsche Marks were disbursed in the same year to externally controlled and low-tech workbenches (e.g., the food industry), which could only maintain their production due to these subventions (Hofmann, 1991, pp. 91-92). Despite short-term catch-up consumption and a prestige-based and superficial boom in the construction industry until the mid-1990s, Berlin's technology and innovation policies represented a loosely moderated, but mostly unfocused and disoriented round table implementing emergency policies (Feuerwehrpolitik) as most commercial and industrial areas were affected by decline and/or plant closures followed by a lost decade (1995-2005) of poor economic dynamics (Kulke, 2008, pp. 196-197; Scheuplein, 1999, p. 48). Two events led to a breakthrough. First, an organizational consolidation, where 
the technology transfer agency merged with the 1994established Technology Foundation (Technologiestiftung Innovationszentrum Berlin, later TSB Technologiestiftung Berlin, and today Technologiestiftung Berlin) in 1999, culminating in a promotion agency for innovation in natural sciences and engineering providing most services in a one-stop shop (later merged with the Business Location Center). Second, a conceptual consolidation broke away from stand-alone technology und incubation centers (e.g., Innovationspark Wuhlheide, Gründerzentrum am Borsigturm) or programs (e.g., Technologieprogramm FIT Berlin 2001 in 1993) to focus on the profiling of technology, innovation, and competence fields (Kompetenzfeldstrategie) accentuating industrial sectors such as healthcare, energy engineering, transportation/ mobility/logistics, information/communication/media/ culture, creative industries, and optics and photonics (Krätke \& Borst, 2000, pp. 71-82). Those efforts gave rise to an innovation and technology concept (Innovationsund Technologiekonzept) by the end of the 1990s and paved the way toward the Coherent Innovation Strategy of Berlin (Kohärente Innovationsstrategie) in 2005. This in turn gave way to the Joint Innovation Strategy of Berlin and Brandenburg (innoBB) in 2011 (updated in 2019, innoBB 2025) in which competence fields were overhauled to create genuine clusters with pertinent cluster master plans (Senate Administration for Economy and Technology, 1993; Senate Administration for Urban Development and Environmental Protection, 1993; Senate Administration for Urban Development, Environmental Protection and Technology, 1999; Senate of Berlin, 2006; Senate of Berlin \& Government of Brandenburg, 2011, 2019). In summary, systematic steps were taken to identify technological fields, assess their innovation potential, explore competencies (by means of outstanding research capacities, flagship projects, acquisition of large-scale third-party funding, competitive product launches, international networks), and turn them into viable clusters (the various innovation strategies mentioned above). Simultaneously, a broader and more open understanding of innovation (e.g., social innovation) combined with trans-sectoral themes (Querschnittsthemen; e.g., clean technologies) attempted to refine (cross-)clusters to create regional platforms or TEM (Senate of Berlin, 2006; Senate of Berlin \& Government of Brandenburg, 2011, p. 14, 2019, pp. 8, 25).

\subsection{The Zukunftsorte Strategy}

The Berliner Zukunftsorte strategy emphasizes 11 futureoriented locations (see Figure 2) embedded in distinct neighborhoods (Transformationsräume) that are capable to act as:

Laboratories for future visions and pivotal places for networking and participation... where living, working, science and culture are to come together, and explo- rative approaches are to be tested how urban and social structures can be preserved or further developed within changing framework conditions. (Senate of Berlin, 2016, p. 7)

The nucleus of the strategy accentuates locations (a) with a spatial concentration of business and science, where (b) an effectively lived exchange and cooperation takes place characterized by (c) sectoral profiling that (d) promotes the innovation and competitiveness of the regional economy (Koglin, 2012, p. 9). Today, according to estimates, Zukunftsorte are home to 42 scientific institutions (including four universities), 2,200 companies, and 62,000 workplaces and provide learning venues for 96,000 students ("Zukunft Berlin-Ideen aus der Metropole. Folge 1," 2020; "Zukunft Berlin-Ideen aus der Metropole. Folge 2," 2020).

The general idea and underlying assumption of Zukunftsorte can be traced back to Berlin's former Senator for Economy and Labor, Elmar Pieroth, who outlined rationales and strategies for commercial and industrial spaces based on "cooperation between the economy, science, and the government" (Senator for Economy and Labor, 1988, p. 87, authors' translation) as early as 1988 . These demands were framed under the heading of technology policy (Technologiepolitik), considered fundamental requirements to establish innovative small and medium-sized industries in high-tech sectors by bringing together economy and science and regularly repeating these encounters (Hofmann, 1993, pp. 171-175; see also Senate Administration for Economy and Technology, 1994). These imperatives acted as guidelines for both planning frameworks and technology/innovation policies when reconstructing the sites of Berlin-Adlershof (see Section 3.1) and Berlin-Buch in former East Berlin (Senate Administration for Economy and Businesses, 1999; Senate Administration for Urban Development, 2011, pp. 17, 51, 59; Senate Administration for Urban Development and Housing, 2020a, pp. 46-47, 103). Later, the concept was applied to further locations all over Berlin with a strong presence of science and research (Standorte mit Wissenschaft und Forschung als prägenden Standortfaktor): Adlershof (A), Buch (B), Charlottenburg (C), Dahlem (D), and Mitte (M) with larger campuses of Berlin's major universities (Lange et al., 2011, p. 9).

The 2012 main manifesto of the Zukunftsorte strategy (Koglin, 2012) ascribed only Adlershof and Buch substantial qualities of Zukunftsorte with potential for the remaining $(A-D, M)$ locations and five further sites to be developed (EUREF Schöneberg, CTM, Schöneweide, and the two former airports Tempelhof and Tegel), joined by Siemensstadt in 2019 after a major decision by the conglomerate to restructure and revive its site. It was obviously a political decision to not fully acknowledge other locations (e.g., Motzener Straße) with favorable prerequisites (Koglin, 2012, pp. 10-11). 
The Urban Tech Republic (1) Siemensstadt 2.0 (2) Berlin Südwest (3) Campus Charlottenburg (4) TechnologiePark Humboldthain (5) Flughafen Tempelhof (6) EUREF Campus (7) Campus Berlin-Buch (8)

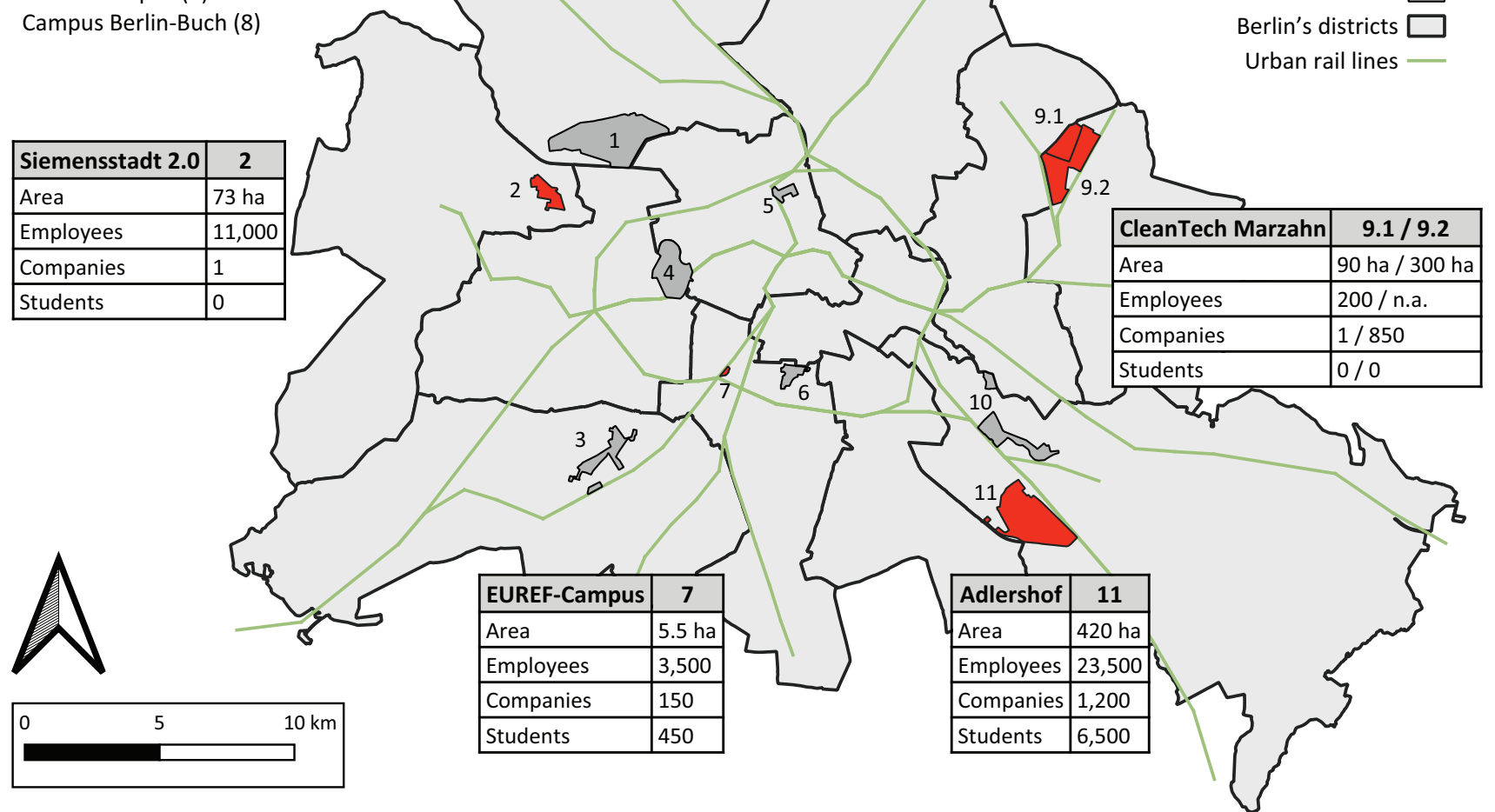

Figure 2. Berlin's Zukunftsorte.

Apart from that, the Zukunftsorte strategy could only unfold its potential since it drew lines to existing innovation/technology initiatives (e.g., innoBB in 2011; Koglin, 2012 , p. 8). Ultimately, a consortium of multiple stakeholder (politics, science, business, society) was leveraged by its issuers, to enter both impending blanket policy agreements (Berlin Strategy 2014, Coalition Agreement 2016-2021; Senate Administration for Urban Development and Environment, 2015, pp. 48; Senate Chancellery, 2016, pp. 52, 84) and specific planning frameworks (UDP Economy 2019; Senate Administration for Economy, Energy and Businesses, 2018a, p. 20; Senate Administration for Urban Development and Housing, 2020a, pp. 25-26). Today, Zukunftsorte can be considered a bridge between pertinent planning frameworks for commercial and industrial spaces and innovation/technology initiatives, embedded in general political and strategic documents. They align with the sector and cluster priorities outlined above (or vice versa) and are therefore capable of channeling substantial business promotion funds from European, national, and municipal sources ("Zukunft Berlin-Ideen aus der Metropole. Folge 3," 2020).

\section{Selected Zukunftsorte Case Studies}

This section examines four examples of Zukunftsorte (Adlershof, CTM, EUREF, and Siemensstadt 2.0) at the
CleanTech Marzahn Originally (9.1) / Extension (9.2) Wirtschafts- und Wissenschaftsstandort Schönweide (10) Adlershof (11) Case studies Other Zukunftsorte Berlin's districts Urban rail lines 
the biggest sciences and technology parks operating in Europe (Adlershof).

\subsection{The Adlershof Zukunftsort}

The general idea behind Zukunftsorte in Berlin was strongly influenced by experiences made during the (re-)development of today's Adlershof Technology Park, located in the south-east of Berlin (Area 11 in Figure 2). Within three decades after reunification, Adlershof was transformed into one of the largest technology parks in Europe with roughly 23,500 employees and 6,500 university students working and studying at 1,200 enterprises, six university institutes, and eight non-university think tanks (WISTA Management, 2020a). Adlershof started as the cradle of Germany's aviation research and production in 1909 and became its most important location before World War II. Thereafter, it was merely transformed into a research site, hosting GDR's Academy of Sciences specialized in natural sciences (e.g., physics and chemistry). German reunification marked another turning point: The Academy of Sciences was significantly downsized from 5,000 to 1,500 employees and integrated into a newly established, nationally financed, (non-)university research network (Leibnitz, Helmholtz, etc.; Kulke, 2008, pp. 197-199; Suwala \& Dannenberg, 2009, p. 133). At the beginning of the 1990s, the 420-hectare area was mainly characterized by empty spaces, abandoned buildings, and outdated infrastructure (Suwala \& Kulke, 2015, pp. 157-158). In 1992, Berlin's administration adopted a master plan and dubbed Adlershof the "city of science and economy." Three pillars earmarked this master plan. First, a Berlinowned but privately organized development and operation company (Entwicklungsgesellschaft Adlershof $\mathrm{mbH}$, today WISTA Management $\mathrm{GmbH}$ ) was commissioned to exploit, develop, and promote the area entirely. Second, many natural science institutes from a major Berlin university were relocated from the city center to Adlershof to complement and strengthen the above-mentioned (non-)university research network. Third, a comprehensive system of technology/innovation-promoting measures was assembled based on university spin-offs, business plan development, business incubators, and segmented technology centers (e.g., for photonics, environmental technologies) to promote tangible and non-tangible infrastructure. Even housing facilities were initially part of the plans (Kulke, 2008, pp. 197-206; Suwala \& Dannenberg, 2009, pp. 106-109).

In 1990 , the site was characterized by mixed ownership ( $63 \%$ by the German Federal Government, $19 \%$ by the city of Berlin, which transferred the land to the operating company WISTA Management, and $8 \%$ by a community association), mostly in public hands. This fact combined with the early uniform designation of the site as an urban development area (urbanes Entwicklungsgebiet) based on the Federal Land Utilization Ordinance on specially designated areas (Sondergebiete; BauNVO,
Section 11 in Federal Ministry of Justice and Consumer Protection, 2021, pp. 8-9) provided reliability for planning; most activities executed on site (e.g., urban development, property marketing, technology promotion, foundation support, facility management) have been executed by a "one-stop agency" for three decades. Although Adlershof fortunes were also influenced by Berlin's lost decade (1995-2005), in particular, housing developments were built with a 15-year delay, the idea of bringing together and connecting business, science, and policymakers and even planners was implemented consistently. Renowned institutions (e.g., HU, Leibnitz, and Helmholtz institutes) are located on site and feature an advanced architectural and technology infrastructure (e.g., the electron accelerator, BESSY II; Dannenberg \& Suwala, 2009, pp. 130-132; Suwala \& Kulke, 2015, pp. 158-162). However, spatial proximity alone does not constitute a well operating Zukunftsort. Considerable and orchestrated efforts (e.g., technology transfer office activities, industry and regional networks, mutual research projects, matchmaking events) were necessary to enhance knowledge flows between the stakeholders and create desired networks and innovations (Brinkhoff et al., 2012, 2015). These processes have been backed by profiled technology centers (e.g., biotechnology, photonics, new materials, and microsystems) thematically in line with operational programs for national and European funds (e.g., OP Berlin EFRE) and striking urban design components (e.g., central agora with the campus zone). Over the past decade, the initial idea of a residential area (beyond the triple helix) was achieved with the construction of 3,000 units for rental housing, condominiums and student apartments, retail and gastronomy, and social infrastructure to form a sustainable and livable neighborhood. These developments propelled an increasing number of employees and students to live on site (Kitzmann \& Kulke, 2021, pp. 44-46; Kulke \& Kitzmann, 2012, pp. 12-15, 2020, pp. 17-20).

\subsection{The CleanTech Marzahn Zukunftsort}

The CTM-with its heart, the CleanTech Business Park (CBP), in Berlin-Marzahn (Area 9.1 in Figure 2)-is arguably the least-developed Zukunftsort of the cases presented here. The 90-hectare site on the northeastern fringe of Berlin is currently a largely undeveloped brownfield that was partly used as a sewage treatment plant until 1990 and afterwards only sparsely used for leisure activities. Ideas to redevelop the site were based on the interest of surrounding companies (solar industry) in space to expand more than a decade ago. Urged by Berlin's planning authorities, the local district administration evaluated options and started to comprehensively demolish, decontaminate, and develop the site predominately as an industrial area in 2009 (District Administration of Marzahn-Hellersdorf, 2019). This transformation was backed by Berlin's economic development authorities and allotted financial resources 
through national (the joint Federal/Länder Task for the Improvement of Regional Economic Structures, GRW) and European funds (EFRD; Senate Administration for Economy, Energy and Businesses, 2021). The district discarded initial ideas for a photovoltaics business park and renamed the core site $\mathrm{CBP}$, which was merely a buzzword at the time but general and promising enough to align with European and national funding schemes and to attract production-oriented companies in renewable, green, and sustainable sectors. The unique selling point of the CBP is the opportunity to host hazardous incident plants (Störfallbetriebe) that cannot settle in ordinary industrial areas (District Administration of Marzahn-Hellersdorf, 2019; Senate Administration for Economy, Energy and Businesses, 2021). Unlike the other Zukunftsorte, CTM constitutes the largest connected open-space industrial plot within the city. An ambivalent advantage is that the core plot (CBP) is currently owned by the city of Berlin and its water management company and is managed by the local district administration (District Administration of Marzahn-Hellersdorf, 2017; Senate Administration for Urban Development and Housing, 2020b). Despite the united and public ownership, only one company (a producer of energyefficient industrial storage media) has settled on the ground (Senate Administration for Economy, Energy and Businesses, 2018b). Reasons for the difficult settlement process are manifold: (a) high commercial demand that does not align with the profile of the CBP (e.g., data and logistic centers); (b) a lack of commercial interest in Berlin's land policy (the city is not selling the land but rather issues building right agreements, or Erbbaurecht); (c) protracted negotiations with the city of Berlin (interested companies turn to other sites, often owned by private developers); and (d) expectations are high and monitoring is precise since the site was publicly subsidized (e.g., long-term employment with mandatory social security contributions, or sozialversicherungspflichtige Beschäftigung) is desired.

The perpetuated industry-related planning of authorities and frameworks (in particular, development concept for the manufacturing-based economy) did a great job securing an industrial spot that can even host hazardous incident plants, but the settlement itself remains difficult. The main ingredients (triple helix) of a Zukunftsort are missing. Despite some well-established and promising local and mid-sized companies with in-house internships and vocational training activities (e.g., Hasse \& Wrede $\mathrm{GmbH}$, Flexim $\mathrm{GmbH}$ ), there are no universities or non-university research institutions on site (Area 9.2 in Figure 2). It comes as no surprise that a former business incubator (2016-2019) offering co-working and workshop space to cleantech-oriented startups (Senate Administration for Economy, Energy and Businesses, 2021) had to close down. The development of the site was initially left to the district administration but will be taken over by the municipally owned WISTA (which also runs Adlershof) in mid-2021. As a prepara- tory measure, CBP (90 hectares, Area 9.1 in Figure 2) was expanded to CTM (300 hectares, Areas 9.1 and 9.2 in Figure 2) including neighboring commercial premises (Gewerbepark Georg Knorr, Econopark Wolfener Straße) and established and thriving companies mentioned above (WISTA Management, 2020b). It remains to be seen whether and when any beneficial impacts will emerge. The potential is there as the CTM Zukunftsort is even part of Berlin's largest connected industrial area (1,200 hectares; Senate Administration for Economy, Energy and Businesses, 2021; Senate Administration for Urban Development and Housing, 2020a, pp. 51-54). Although neither CBP nor CTM contain residential space, they border directly on the city's two largest former Socialist large-scale housing developments (Marzahn with 60,000 housing units and Hohenschönhausen with $40,000)$. In the near future, more than 2,000 additional residential units will be established by city-owned housing companies, housing associations, and private developers in these neighborhoods (own calculations). Future planning efforts-currently spearheaded by the city's planning and economic development office-have two objectives. One involves a new business incubator and, in the long run, even a university campus. The other entails a new strategy for smaller plots (even less than one hectare) to meet changing demands.

\subsection{The EUREF Campus Berlin Zukunftsort}

EUREF covers an area of only 5.5 hectares and is located on the south-western edge of Berlin's inner city, within a triangle of houses and railway tracks (Area 7 in Figure 2). The site has a long history as an industrial area with an urban gas production and supply depot. In 1871, the British Imperial Continental Gas Association-the market leader in municipal gas supply of its time-erected the first gas-fired power plant as coal could be delivered easily here by rail. This plant was replaced in 1910 by a novel 78-meter-high gasometer-the third biggest in Europe as measured by the capacity to store gas-with a characteristic steel structure that gives the site its distinctive image to this day. The plant was shut down in 1946 , but the gasometer remained in operation by the municipally owned gas provider GASAG as a gas storage facility until 1995 when it was dismantled (GASAG, 2021). In Berlin's lost decade (1995-2005), the underdeveloped area-still equipped with historic buildings (e.g., low-pressure gas tank, retort house, boiler house with water tower, etc.)-was used only by small businesses to store, park, and service motor vehicles. In 2007, an architect known for restoration-and heritage-related restoration in the city purchased the site with a vision (District Administration of Tempelhof-Schöneberg, 2012). This vision was grounded in developing a concept for a European energy forum consisting of offices, teaching and research facilities, and spaces for the location of European power generating businesses complemented by event venues, accommodation and boarding houses, 
and catering services. By means of a carbon-neutral energy supply, a smart energy grid, energy-efficient buildings, an experimental platform for electromobility, and numerous research projects, the campus strives to prove that the energy transition (Energiewende) is feasible and financially viable. EUREF already achieved the German government's $\mathrm{CO}_{2}$ emissions reduction goal for the year 2050 in 2014. Currently, 3,500 people are employed there at more than 150 companies, institutions, and start-ups in the fields of energy, mobility, and sustainability (EUREF, 2021).

The new owner, his vision, and the resulting private investment interest triggered the district to regulate the fortunes in the area by means of a binding CLUP (Bebauungsplan). The required framework conditions were provided to revitalize the old industrial site for new use endowed with national funding (GRW). According to the city's LUP, the site is dedicated for mixed-land use (gemischte Baufläche) open to manifold types of industrial and commercial valorization and therefore offers developer a high degree of freedom (District Administration of Tempelhof-Schöneberg, 2012). Since most of the properties are owned by EUREF AG (private stock cooperation), this private-sector developer of low-energy and environmentally optimized immovables can be considered the operation company and main orchestrator on site. Over the years, EUREF AG has been able to convince both reputable companies (e.g., Deutsche Bahn, Cisco, Schneider Electric, GASAG) and established research institutions (e.g., Technische Universität Berlin, Mercator Research Institute on Global Commons and Climate Change $\mathrm{GmbH}$ ) to set up shop on site. These institutions work on mutual projects (e.g., Inno Z, 2008-2019, a partnership between two non-university think tanks and Deutsche Bahn), which are often also promoted by flagship projects of German Federal Ministries (e.g., Mobility2Grid). The Mobility2Grid project brings together partners from (non-)university think tanks and the private sector. All these initiatives attempt to simulate a futuristic urban vision by means of a living lab (Reallabor) and aim to jointly contemplate the use of renewable energies with emerging trends in urban mobility (EUREF, 2021). Further initiatives encompass co-working spaces, incubators, labs (e.g., Infralab Berlin), and accelerators (e.g., the Climate-KIC Green Garage). The Infralab project is a joint innovation laboratory run by municipal services and infrastructure providers (e.g., the BVG for mobility; the BWB for water; BSR for city cleaning; GASAG for gas works; the Vattenfall Wärme Berlin for heating; Stromnetz Berlin for power; and Veolia for waste disposal), where start-ups and bright minds are given the opportunity to put forth new ideas (Merkel \& Suwala, 2021).

\subsection{The Siemensstadt 2.0 Zukunftsort}

The most recently labeled Zukunftsort, Siemensstadt, looks back on the longest industrial history of the four case studies presented here (Area 2 in Figure 2). It was both the central location of the renowned electrical company of Siemens during the interwar period, which was the biggest of its kind in the world (Bähr, 2001, pp. 25-27), and a significant pillar for Berlin Electropolis as Europe's center for the emerging electrical industry (Schultze, 1927, pp. 519-521). Siemens started its venture-in a district that would officially be named Siemensstadt in 1914-as a greenfield development in 1897 with a cable-manufacturing plant (established in 1899). The spacious site and the foresighted planning allowed for the constant expansion of both production (e.g., iron foundry in 1908, power station in 1912, telephone exchange in 1913, research laboratory in 1920) and housing facilities (e.g., company-owned accommodation, or Werkswohnungsbau) starting in 1904. Later, the modern Ringsiedlung Siemensstadt settlementnow a UNESCO world-heritage site-was erected, featuring 1,370 housing units, a combined heat and power plant, laundry facilities, shops, and even a school (Klünner, 1978, pp. 71-86). In a nutshell, Siemens developed an entire district with a mix of industrial production, housing, administrative and social functions, parks, and infrastructure. By the end of the 1930s, the 212-hectare site was home to 13,000 residents and 65,000 employees (Imsirovic, 2020, p. 16). After World War II, Siemens followed a decentralization strategy, relocating its hub to southern Germany (Munich and Erlangen). Left as the "second" headquarters, the administration buildings in Siemensstadt were repurposed into production space, and the central administration building was used again for its original purpose only starting in 1976 (Siemens AG, 2021). Although Siemens' current production volume in Siemensstadt is nowhere near historical figures, the 11,000 employees on site make it the company's largest production site worldwide. Hence, it comes as no surprise that Siemens will invest 600 million euros to transform a selected 73-hectare industrial site into Siemensstadt 2.0 by 2030 , representing the company's largest ever investment in a single project (Siemens AG, 2021). Ninety-seven percent of the area is owned by Siemens, $2 \%$ by the city and $1 \%$ by private stakeholders, forming a unified property basis to complete such a mega project (Senate Administration for Urban Development and Housing, 2020c, p. 9).

Compared to the preceding case studies, Siemensstadt 2.0 is the only Zukunftsort that will primarily be created by a single company. In 2018, Siemens and the city of Berlin signed a memorandum of understanding for the creation of this future-oriented neighborhood that combines working, housing, and research following the principle of an "industrial smart city" (Imsirovic, 2020, pp. 16-18; Kögl, 2020, pp. 73-74). The planning and development process encompasses a joint venture between Siemens and a total of 70 employees from various city administration units in manifold working groups, demonstrating Berlin's commitment to the project. Research and teaching activities have mainly been 
organized internally to date; with regard to teaching, the on-site Siemens Professional Education is one of the largest German in-house education facilities and offers dual vocational education and training (Siemens AG, 2013). Missing universities and external connections between production, research, and knowledge transfer are substituted by novel initiatives (e.g., the launch of the Werner-von-Siemens Centre for Industry and Science, with joint professorships with Technische Universität Berlin, an agreement between this university, the city of Berlin, and two non-university research institutions; Kögl, 2020, p. 74; Werner-von-Siemens Centre for Industry and Science e.V., 2021). The main areas of research and production will be electrical mobility, IT and automatization, artificial intelligence, new materials, and additive manufacturing (Werner-von-Siemens Centre for Industry and Science e.V., 2021). Siemensstadt 2.0 is planned as a mixed-use neighborhood following the idea of a compact city with short distances (Stadt der kurzen Wege). Around 38 hectares will be redeveloped for the following purposes: (a) a 5.4-hectare plot for housing complemented by green spaces and a kindergarten; (b) a 1.4-hectare plot for office use; (c) a 24-hectare core for housing, commercial use, and leisure, including 3.8 hectares of green spaces; and (d) 7 hectares for offices, commercial use, and research. A total of 2,750 housing units are planned by 2030 (Senate Administration for Urban Development and Housing, 2020c, pp. 11-64). In order to realize these plans, changes to Berlin's LUP will be necessary and were initiated in 2019; for example, an area formerly meant solely for industry (BauNVO, Section 9; Federal Ministry of Justice and Consumer Protection, 2021, p. 8) will be opened for housing and social infrastructure (gemischte Baufläche). The first repurposing tasks have passed the stage of early public participation and must be approved by the development concept for the manufacturing-based economy (Senate Administration for Urban Development and Housing, 2020b, p. 134, 2020c, pp. 25-28).

\subsection{Comparative Assessment}

Table 1 summarizes the main results from the case studies and allows for an overall assessment of how the distinctive Zukunftsorte were facilitated by planning frameworks and technology/innovation initiatives and to what extent they already share components of TEM necessary to transform commercial and industrial areas into innovative, viable, and vibrant urban areas of the future. Adlershof is a textbook example and role model for the overall idea behind Zukunftsorte today. Early on, in 1992, separate statutory provisions, a master plan, and a vision were enacted to create a "city of science and economy" with designated areas for business, science, and housing providing a holistic concept. The statutory provisions secured the area as a specially designated area (Sondergebiet; BauNVO, Section 11 in Federal Ministry of Justice and Consumer Protection,
2021, pp. 8-9), while the master plan indicated a strong political will. The master plan was managed, propelled forward, and implemented over the course of the last 30 years by the city-owned operating company (WISTA Management GmbH) and its planning subsidiary (WISTA Plan GmbH, formerly Adlershof Projekt $\mathrm{GmbH}$ ) with a great impact on municipal planning and the citywide political agenda. The results are high-capacity networks between world-leading high-tech SMEs, various (non-)university institutions, and policy/planning stakeholders. The site constitutes a well working TIM. This venture, however, required a local research tradition and strong local entrepreneurial will after reunification. It started with unified ownership based on a long-term strategy and profited from farsighted planning and management to channel funds and attract investors. It will be interesting to see in the future whether current residential efforts and the development of utility infrastructure (gastronomy, retail, etc.) will be able to transform the area into a viable urban area (TEM). CTM possesses the city's largest connected open-space industrial plot able to host hazardous incident plants that is well secured by planning regulations (Industriegebiet; BauNVO, Section 9 in Federal Ministry of Justice and Consumer Protection, 2021, p. 8). Apart from this, the main elements of Zukunftsorte are missing and/or not connected with each other. An inflexible location development and marketing strategy coupled with a lack of research institutions, isolated adjacent commercial and industrial properties, and surrounding residential areas pose major challenges. Even though the territory was extended beyond the initial plot, a long and coherent journey will be needed not only to locate fundamental TIM components (e.g., research institutions), but also to create synergies between them. EUREF is an inspiring locational forge of creativity bolstered by binding planning regulations (CLUP) as a mixed-land use area with high degrees of freedom (gemischte Baufläche). Due to its very limited size, however, EUREF feels more like a cleverly managed and extended show room with multiple convention centers, event locations, and top cuisine rather than a fully envisioned Zukunftsort despite being a steppingstone for some start-ups. Taking the surrounding area into account, the site still gives the impression of a "work island," since its location on suburban railway lines hinders adequate integration into the urban fabric, which is largely disconnected from the site. Apart from boarding houses for temporary visitors, no housing is planned. All in all, EUREF superficially unites all the components of TIM and partly of TEM, however, it is merely a miniature version of a Zukunftsort that evokes an exhibition and trade fair venue. The Siemensstadt 2.0 idea is relatively new, and the assessment of it is highly speculative. Its greatest advantage-planning and development under one roof-could make it highly dependent on the industrial conglomerate, although the planning process to date has been very transparent. The entire area, and in particular the 38-hectare core 
Table 1. Characteristics of the case studies.

\begin{tabular}{|c|c|c|c|c|}
\hline Criteria & Adlershof & CleanTech Marzahn & EUREF Campus Berlin & Siemensstadt 2.0 \\
\hline \multicolumn{5}{|l|}{ Components of TEM } \\
\hline $\begin{array}{l}\text { Regulations/planning } \\
\text { (neglected part of } \\
\text { politics) }\end{array}$ & $\begin{array}{l}\text { Separate master plan } \\
\text { and vision as a City of } \\
\text { Science and Economy } \\
\text { with designated } \\
\text { areas for business, } \\
\text { science, and housing; } \\
\text { in-house planning } \\
\text { subsidiary-majority } \\
\text { of (in)formal planning } \\
\text { frameworks }\end{array}$ & $\begin{array}{l}\text { The city's largest } \\
\text { connected } \\
\text { open-space industrial } \\
\text { plot with the city able } \\
\text { to host hazardous } \\
\text { incident plants } \\
\text { (development } \\
\text { concept for } \\
\text { production-oriented } \\
\text { areas, UDP } \\
\text { Economy 2030) }\end{array}$ & $\begin{array}{l}\text { Binding CLUP plan as } \\
\text { mixed-land use area } \\
\text { with high degrees of } \\
\text { freedom }\end{array}$ & $\begin{array}{l}\text { Company-owned } \\
\text { property secured as } \\
\text { commercial, } \\
\text { industrial, and } \\
\text { residential site by } \\
\text { partly changing } \\
\text { zoning into mixed } \\
\text { areas (changes in LUP, } \\
\text { development } \\
\text { concept for } \\
\text { production-oriented } \\
\text { areas, UDP } \\
\text { Economy 2030) }\end{array}$ \\
\hline Business & $\begin{array}{l}\text { High-tech SMEs and } \\
\text { hidden champions }\end{array}$ & $\begin{array}{l}\text { A few traditional and } \\
\text { modern SMEs and } \\
\text { crafts for local supply }\end{array}$ & $\begin{array}{l}\text { Living lab/showroom } \\
\text { for renowned } \\
\text { companies }\end{array}$ & $\begin{array}{l}\text { Stand-alone } \\
\text { world-leading } \\
\text { conglomerate }\end{array}$ \\
\hline Science & $\begin{array}{l}\text { Top-tier university } \\
\text { with pertinent faculty } \\
\text { on site }\end{array}$ & Not on site & $\begin{array}{l}\text { Flagship project of } \\
\text { Federal Ministries, } \\
\text { pilot study programs }\end{array}$ & $\begin{array}{l}\text { Mostly in-house R\&D, } \\
\text { first linkages to } \\
\text { Berlin's science } \\
\text { landscape }\end{array}$ \\
\hline Politics & $\begin{array}{l}\text { City-owned operating } \\
\text { company with great } \\
\text { impact on the } \\
\text { political agenda }\end{array}$ & $\begin{array}{l}\text { Inflexible location } \\
\text { development and } \\
\text { marketing strategy }\end{array}$ & $\begin{array}{l}\text { Operating company } \\
\text { with a } \\
\text { well-elaborated } \\
\text { real-estate } \\
\text { exploitation strategy }\end{array}$ & $\begin{array}{l}\text { Decisions of } \\
\text { conglomerate have } \\
\text { political clout }\end{array}$ \\
\hline Housing & $\begin{array}{l}\text { Various newly } \\
\text { constructed } \\
\text { residential units with } \\
\text { varying degrees of } \\
\text { connection (e.g., } \\
\text { student apartments, } \\
\text { single-family } \\
\text { housing) }\end{array}$ & $\begin{array}{l}\text { Lack of integration } \\
\text { into adjacent former } \\
\text { Socialist large-scale } \\
\text { neighborhoods }\end{array}$ & $\begin{array}{l}\text { Only boarding houses } \\
\text { for temporary } \\
\text { visitors, lack of } \\
\text { integration into } \\
\text { surrounding } \\
\text { neighborhoods }\end{array}$ & $\begin{array}{l}\text { Historical company } \\
\text { housing, designated } \\
\text { areas for new } \\
\text { residential } \\
\text { development }\end{array}$ \\
\hline Assessment & $\begin{array}{l}\text { Textbook example of } \\
\text { Zukunftsort } \\
\text { (established } \\
\text { networks between } \\
\text { business, science) } \\
\text { with new residential } \\
\text { efforts }\end{array}$ & $\begin{array}{l}\text { Industrial plot with } \\
\text { great potential but } \\
\text { many missing links }\end{array}$ & $\begin{array}{l}\text { Extended showroom } \\
\text { for business and } \\
\text { science with event } \\
\text { and convention } \\
\text { spaces }\end{array}$ & $\begin{array}{l}\text { Infant stage of } \\
\text { transforming a } \\
\text { traditional industrial } \\
\text { space into a modern } \\
\text { working and living } \\
\text { environment }\end{array}$ \\
\hline
\end{tabular}

being redeveloped, commemorates the master plan of Adlershof and the vision of a futuristic urban quarter where initial changes in the LUP from industrial toward mixed-use areas (gemischte Baufläche) have been initiated. It will be interesting to see in the future whether these mostly closed corporate premises can be transformed into an open campus with a thriving research community, start-ups, and residential areas connected beyond the reach of the conglomerates. Planning efforts are already underway.

\section{Conclusions}

By combining an urban planning and regional innovation studies perspective, we were able to shed light on the link that is often missing between both disciplines: 
the lack of innovation in planning (Ibert, 2003) and the largely neglected anchoring of planning in TIM (Cooke, 2011). Additionally, our main intention was to add the civic society (housing, fourth helix) and planning frameworks (regulations, a distinctive part of the third helix) in order to extend conventional TIM to TEM. For this reason, we explicitly selected the liminal strategy of Berliner Zukunftsorte, which is applicable to both planning frameworks and technology/innovation policies. The Zukunftsorte strategy attempts to develop former commercial and industrial brownfields by preserving their historic sites and modernizing their commercial and industrial base. Based on the ideas behind TIM or the triple helix that innovation flourishes with co-located and interconnected stakeholders-including companies from related industries along value chains (business), academic entities, and governmental institutions - we postulate that these areas should additionally be embedded in residential neighborhoods and supported by appropriate planning frameworks in order to facilitate the development of viable urban areas capable of offering spaces for living, working, education, culture, and leisure within close proximity (TEM). What sounds simple in theory is difficult to implement in reality because this requires mixeduse areas. Results have shown that neither planning and innovation policies in Berlin in general nor planning and innovation initiatives in distinctive Berlin Zukunftsorte in particular, are straightforward, and, ultimately, they depend on persistent trajectories of the past, political power relations, the economic situation, and contextspecific site characteristics. With regard to planning, various planning regulations (e.g., LUP and CLUP in combination with industrial zones, Industriegebiet, or specially dedicated areas, Sondergebiet; see BauNVO, Sections 9 and 11 respectively, in Federal Ministry of Justice and Consumer Protection, 2021, pp. 8-9) backed by informal planning documents for commercial and industrial spaces (development concept for production-oriented areas, "economic" UDPs) led to the desired objectives. Interestingly, the newly introduced building law category "urban area" (Urbanes Gebiet; BauNVO, Section 6a in Federal Ministry of Justice and Consumer Protection, 2021, pp. 6-7) has not been used in Berlin so far, mainly because of two alternatives that both also allow for mixed-use areas: An idiosyncratic equivalent is the mixed-use area (gemischte Baufläche) and a way around it is the specially dedicated area (urbanes Entwicklungsgebiet). With regard to technology/innovation policies, most Zukunftsorte are in different stages of the life cycle and are in need of customized tools. Adlershof is a well-functioning network of business, academia, and policymakers with preliminary attempts to embed those stakeholders in residential neighborhoods - therefore, it is partly on its way to becoming a TEM. Where EUREF is miniature version of Adlershof or a living lab of Zukunftsorte (without housing), the other selected Zukunftsorte do not yet deserve this name as basic TIM/TEM components are still missing. Therefore, Berlin will have to undertake manifold strategies toward its (new) commercial and industrial spaces in the future (Gornig \& Werwatz, 2018). Our results showed the value added and idea by incorporating planning frameworks and housing efforts into TIM is imaginable well beyond the context of Berlin. To understand TEM comprehensively, the study should be extended to the fifth helix (the environment) in the future.

\section{Acknowledgments}

We acknowledge the support of Hardy Schmitz, Roland Sillmann, Helge Neumann, and Mirjam Landowski who provided diverse insight about historical, current, and future facts and circumstances with regard to the planning frameworks, political processes, and effective management of selected Zukunftsorte.

\section{Conflict of Interests}

The authors declare no conflict of interests.

\section{References}

Bähr, J. (2001). Industrie im geteilten Berlin (1945-1990): Die elektrotechnische Industrie und der Maschinenbau im Ost-West-Vergleich-Branchenentwicklung, Technologien und Handlungsstrukturen [Industry in divided Berlin (1945-1990): The electrotechnical industry and engineering in east-west comparisonSector development, technologies and agency structures]. De Gruyter.

Brandt, M., Butzin, A., Gärtner, S., Meyer, K., Hennings, G., Siebert, S., \& Ziegler-Hennings, C. (2017). Produktion zurück ins Quartier? Neue Arbeitsorte in der gemischten Stadt [Manufacturing back with the neighborhood? New workplaces in the assorted city]. Institute for Work and Technology.

Brinkhoff, S., \& Kitzmann, R. (2014). Urban dreams and economic realities-Areas of innovation between the demands of the knowledge society and the requirements of innovative industries. In 31st IASP world conference (pp. 263-279). International Association of Science Parks and Areas of Innovation.

Brinkhoff, S., Suwala, L., \& Kulke, E. (2012). What do you offer? Interlinkages of universities and hightechnology companies in science and technology parks in Berlin and Seville. In R. Capello, A. Olechnicka, \& G. Gorzelak (Eds.), Universities, cities and regions. Loci for knowledge and innovation creation (pp. 121-146). Routledge. https://doi.org/10.4324/ 9780203097144-15

Brinkhoff, S., Suwala, L., \& Kulke, E. (2015). Managing innovation in 'localities of learning' in Berlin and Seville. In G. Micek (Ed.), Understanding innovation in emerging economic spaces (pp. 11-31). Ashgate. https://doi.org/10.4324/9781315549163-9 
Cooke, P. (2011). Transition regions: Regional-national eco-innovation systems and strategies. Progress in Planning, 76(3), 105-146. https://doi.org/10.1016/ j.progress.2011.08.002

Dannenberg, P., \& Suwala, L. (2009). Der Wirtschaftsund Wissenschaftsstandort Berlin-Adlershof: Herausbildung eines politisch induzierten innovativen Milieus? [The business and science location BerlinAdlershof: Emergence of a politically induced innovative milieu?], In P. Dannenberg, H. Köhler, T. Lang, J. Utz, B. Zakirova, \& T. Zimmermann (Eds.), Innovationen im Raum - Raum für Innovationen [Innovations in space - Space for innovations] (pp. 128-141). ARL.

Der Regierende Bürgermeister von Berlin. (2000). Die BerlinStudie-Strategien für die Stadt [The Berlin study-Strategies for the city]. Regioverlag.

District Administration of Marzahn-Hellersdorf. (2017). CleanTech Business Park-Generating the future.

District Administration of Marzahn-Hellersdorf. (2019). Exposé-Industrial space in the CleanTech Business Park Berlin Marzahn.

District Administration of Tempelhof-Schöneberg. (2012). Development plan XI-231b explanatory memorandum.

Ebneyamini, S., \& Moghadam, M. R. S. (2018). Toward developing a framework for conducting case study research. International Journal of Qualitative Methods, 17(1), 1-11. https://doi.org/10.1177/160940 6918817954

Ellger, C. (1992). Berlin: Legacies of division and problems of unification. Geographical Journal, 158(1), 40-46. https://doi.org/10.2307/3060015

European Energy Forum. (2021). EUREF campus Berlin. https://euref.de

Federal Ministry of Justice and Consumer Protection. (2021). Verordnung über die bauliche Nutzung der Grundstücke (Baunutzungsverordnung - BauNVO) [Ordinance on the building utilization of premises (Federal Land Utilization Ordinance - FLUO).

GASAG. (2021). Geschichte der GASAG [GASAG history map]. https://gasaghistorymap.azurewebsites.net

Gornig, M., \& Werwatz, A. (2018). Anzeichen für eine Reurbanisierung der Industrie [Signs of a reurbanisation of the industry]. Wochenbericht, 85(47), 1006-1011.

Henckel, D., Grabow, B., Knopf, C., Nopper, E., Rauch, N., \& Regitz, W. (1986). Produktionstechnologien und Raumentwicklung [Production technologies and spatial development]. Kohlhammer-Deutscher Gemeindeverlag.

Hofmann, J. (1991). Innovationsförderung in Berlin und Baden-Württemberg: Zum regionalen Eigenleben technologiepolitischer Konzepte [Innovation promotion in Berlin and Baden-Wuerttemberg: Regional independence of technology political concepts]. In U. Jürgens \& W. Krumbein (Eds.), Industriepolitische Strategien: Bundesländer im Vergleich [Strategies of industrial policies: German Federal states in compar- ison] (pp. 74-97). Edition Sigma.

Hofmann, J. (1993). Implizite Theorien in der Politik: Interpretationsprobleme regionaler Technologiepolitik [Implicit theories in politics: Problems of interpretation of regional technology policy]. Westdeutscher.

Ibert, O. (2003). Innovationsorientierte Planung. Verfahren und Strategien zur Organisation von Innovation [Innovation-oriented planning. Processes and strategies for the organization of innovation]. Leske + Budrich.

Imsirovic, T. (2020). Höhenflug in Spandau [Soaring in Spandau]. Bauwelt, 7, 16-19.

Kitzmann, R., \& Kulke, E. (2021). Der Technologiepark Berlin-Adlershof-Auf dem Weg zum multifunktionalen Stadtquartier!? [The technology park Berlin-Adlershof-Towards a multifunctional urban neighborhood!?]. Geographische Rundschau, 73(6), 44-49.

Kitzmann, R., \& Suwala, L. (2018). Oberschöneweide oder Oberschweineöde? Ein Berliner Altindustriestandort im Zeichen der Revitalisierung [Oberschöneweide or Oberschweineöde? An old industrial area in Berlin characterized by revitalization]. Geographische Rundschau, 70(11), 42-48.

Klünner, H. W. (1978). Spandau und Siemensstadt so wie sie waren [Spandau and Siemensstadt as they were]. Droste.

Kögl, S. (2020). Vom Industriestandort zum lebendigen Teil der Stadt-Siemensstadt 2.0 als "Smart District" in Berlin. [From an industrial site to a vivid part of the city-Siemensstadt 2.0 as "smart district" in Berlin]. Forum Wohnen und Stadtentwicklung, 2, 73-76.

Koglin, G. (2012). Berliner Zukunftsorte-Wo aus Wissen Arbeit wird [Berlin's Zukunftsorte-Where knowledge becomes labor]. Technologiestiftung Berlin.

König, J., Suwala, L., \& Delargy, C. (2020). Helix models of innovation and sustainable development goals. In W. Leal Filho, A. M. Azul, L. Brandli, A. Lange Salvia, \& T. Wall (Eds.), Industry, innovation and infrastructure. Encyclopedia of the UN sustainable development goals (pp. 1-15). Springer. http://dx.doi.org/ 10.1007/978-3-319-71059-4_91-1

Krätke, S., \& Borst, R. (2000). Berlin: Metropole zwischen Boom und Krise [Berlin: Metropolis between boom and crisis]. Leske + Budrich.

Kulke, E. (2003). Berlin-German capital and global city? Die Erde, 134(3), 219-233.

Kulke, E. (2008). The technology park Berlin-Adlershof as an example of spatial proximity in regional economic policy. Zeitschrift für Wirtschaftsgeographie, 52(4), 193-208. https://doi.org/10.1515/zfw.2008.0015

Kulke, E., \& Kitzmann, R. (2012). Der Standort Adlershof aus Sicht der Beschäftigten-Ergebnisse einer repräsentativen Erhebung unter Studierenden und Beschäftigten in Berlin Adlershof, Stadt für Wissenschaft, Wirtschaft und Medien [The site Adlershof from the perspective of the employees-Results of a representative survey among students and employ- 
ees in Berlin-Adlershof, city of science, economy and media] (Arbeitsberichte Geographisches Institut No. 171). Humboldt University of Berlin.

Kulke, E., \& Kitzmann, R. (2020). Vom monofunktionalen Arbeitsort zum multifunktionalen Stadtquartier? Bewertung und Wahrnehmung des Technologieparks Berlin-Adlershof durch Studierende und Beschäftigte [From a monofunctional work site to a multifunctional urban neighborhood] (Arbeitsberichte Geographisches Institut No. 199). Humboldt University of Berlin.

Kulke, E., \& Suwala, L. (2015). Wirtschaftsgeographie Berlins-Entwicklungspfade und vernetzte Raumkonfiguration [Economic geography of BerlinDevelopment trajectories and interconnected spatial configutations]. In M. Makki \& R. Kleßen (Eds.), Exkursionen Deutscher Kongress für Geographie 2015 [Excursion guide for the German Congress on Geography 2015] (pp. 44-54). Humboldt University of Berlin.

Lange, D., Piesbergen, M., Rohn, K., Schmitz, H. R., \& Suwala, L. (2011). Nachhaltige Vitalisierung des kreativen Quartiers um den Campus BerlinCharlottenburg [Sustainable vitalization of the creative neighborhood around the Campus BerlinCharlottenburg]. Adlershof Projekt $\mathrm{GmbH}$.

Merkel, J., \& Suwala, L. (2021). Intermediaries, work and creativity in innovative and creative sectors: The case of Berlin. In B. J. Hracs, T. Brydges, T. Haisch, A. Hauge, J. Jansson, \& J. Sjöholm (Eds.), Culture, creativity and economy: Collaborative practices, value creation and spaces of creativity (pp. 56-69). Routledge.

Moulaert, F., \& Sekia, F. (2003). Territorial innovation models: A critical survey. Regional Studies, 37(3), 289-302. https://doi.org/10.1080/00343400 32000065442

Scheuplein, C. (1999). Friedrich List und die "neue Mitte." Sozialdemokratische Technologiepolitik in der Metropole Berlin [Friedrich List and the "new center." Social democratic technology politics in the metropolis of Berlin]. UTOPIE kreativ, 108, 46-56.

Schmidt, S., Müller, F. C., Ibert, O., \& Brinks, V. (2018). Open region: Creating and exploiting opportunities for innovation at the regional scale. European Urban and Regional Studies, 25(2), 187-205. https://doi. org/10.1177/0969776417705942

Schultze, E. H. (1927). Die Siemens-Werke in BerlinSiemensstadt [The Siemens plant in BerlinSiemensstadt]. In Schiffbautechnische Gesellschaft zu Berlin (Ed.), Jahrbuch der Schiffbautechnischen Gesellschaft [Yearbook of the Naval Engeneering Society] (Vol. 28, pp. 519-551). Springer.

Senate Administration for Economy and Businesses. (1999). Stadtentwicklungsplan Gewerbe. Gewerbestandort Berlin [Urban development plan on commerce. Berlin as commercial location].

Senate Administration for Economy and Technology. (1993). Konzept zur Sicherung von Gewerbe- und
Industrieflächen in wichtigen Bereichen Berlins [Concept on protecting commercial and industrial spaces in important areas of Berlin].

Senate Administration for Economy and Technology. (1994). Transfer Berlin - Kooperationen zwischen Wissenschaft und Wirtschaft [Transfer BerlinCooperation between science and business].

Senate Administration for Economy, Energy and Businesses. (2018a). Masterplan Industriestadt Berlin 2018-2021 [Master plan industrial city Berlin 2018-2021].

Senate Administration for Economy, Energy and Businesses. (2018b). Erste Ansiedlung im Zukunftsort CleanTech Business Park Berlin-Marzahn [First Settlement in the CTP Berlin Marzahn].

Senate Administration for Economy, Energy and Businesses. (2021). CleanTech Marzahn.

Senate Administration for Urban Development and Environment. (2015). BerlinStrategy-Urban development concept 2030.

Senate Administration for Urban Development and Environmental Protection. (1993). Konzept zur Industrieflächensicherung [Concept for industrial area protection].

Senate Administration for Urban Development and Housing. (2020a). Stadtentwicklungsplan Wirtschaft 2030-Entwicklungspotenziale für Gewerbe und Industrie [Urban development plan for economy 2030-Development potentials for commerce and industry].

Senate Administration for Urban Development and Housing. (2020b). Flächennutzungsplan Berlin-Stand September 2020 [Land use plan Berlin-Effective September 2020].

Senate Administration for Urban Development and Housing. (2020c). Erläuterung zum Bebauungskonzept für den Bebauungsplan 5-123 (Siemensstadt 2.0) [Explanations on the building concept for the development plan 5-123 (Siemensstadt 2.0)].

Senate Administration for Urban Development, Environmental Protection and Technology. (1999). Innovations- und Technologiekonzept [Innovation and technology concept].

Senate Administration for Urban Development. (2004). Stadtentwicklungskonzept-Berlin 2020. Statusbericht und perspektivische Handlungsansätze [Urban development concept-Berlin 2020. Status report and perspectival action approaches].

Senate Administration for Urban Development. (2011). Stadtentwicklungsplan Industrie und GewerbeEntwicklungskonzept für den produktionsgeprägten Bereich [Urban development plan for industry and commerce-Development concept for productionoriented areas].

Senate Chancellery. (2016). Koalitionsvereinbarung zwischen Sozialdemokratische Partei Deutschlands (SPD) Landesverband Berlin und DIE LINKE Landesverband Berlin und BÜNDNIS 90/Die Grünen Landesverband 
Berlin für die Legislaturperiode 2016-2021 [Coalition agreement between the Social Democratic Party of Germany (SPD) Landesverband Berlin and DIE LINKE Landesverband Berlin and BÜNDNIS 90/Die Grünen Landesverband Berlin for the legislative period 2016-2021].

Senate of Berlin, \& Government of Brandenburg. (2011). Gemeinsame Innovationsstrategie der Länder Berlin und Brandenburg (innoBB) [Joint innovation strategy of the federal states of Berlin and Brandenburg (innoBB)].

Senate of Berlin, \& Government of Brandenburg. (2019). innoBB 2025-Gemeinsame Innovationsstrategie der Länder Berlin und Brandenburg [innoBB 2025-Joint innovation strategy of the federal states of Berlin and Brandenburg].

Senate of Berlin. (2006). Innovations-, Forschungsund Technologieleistungen des Landes Berlin (LandesInnovationsbericht; Drucksache Nr. 15/5534) [Innovation, research and technology performance in Berlin (Federal state innovation report; Printed matter No. 15/5534)].

Senate of Berlin. (2016). Digitalisierung (Drucksache Nr. 17/2600) [Digitalization (Printed matter No. 17/ 2600)].

Senator for Economy and Labor. (1988). 18. Bericht über die Lage der Berliner Wirtschaft [18th report on Berlin's economic situation].

Siemens AG. (2013). Siemens Professional EducationLaufbahnmodelle IT [Siemens professional education-Career models in IT; PowerPoint Presentation]. https://docplayer.org/5999841-Siemensprofessional-education-laufbahnmodelle-it.html

Siemens AG. (2021). Die neue Siemensstadt. [The novel Siemensstadt Siemens]. https://www.siemensstadt. siemens.com/de

Suwala, L., \& Dannenberg, P. (2009). Cluster- und Innovationspolitik maßgeschneidert. Das Beispiel Adlershof in Berlin [Cluster and innovation policy customized. The case of Adlershof in Berlin]. Standort, 33(4), 104-112. https://doi.org/10.1007/ s00548-009-0122-4

Suwala, L., \& Kulke, E. (2015). Der Technologiepark Berlin-Adlershof-Von der Wiege der deutschen Luftfahrt bis zur gegenwärtigen Stadt für Wissenschaft, Wirtschaft und Medien [The technology park BerlinAdlershof-From the cradle of German aviation to the current city of science, economy and media]. In M. Makki \& R. Kleßen (Eds.), Exkursionsführer zum
Deutschen Kongress für Geografie 2015 in Berlin: Herausforderungen von Mensch-Umwelt-Beziehungen im 21. Jahrhundert [Excursion guide for the German Congress on Geography 2015 in Berlin: Challenges of human-environmental relations in the 21st century] (pp. 156-165). Humboldt University of Berlin.

Suwala, L., \& Micek, G. (2018). Beyond clusters? Field configuration and regional platforming: The Aviation Valley initiative in the Polish Podkarpackie region. Cambridge Journal of Regions, Economy and Society, 11(2), 353-372. https://doi.org/10.1093/cjres/ rsy010

Wagner-Endres, S., Wolf, U., \& Zwicker-Schwarm, D. (2018). Neue Konzepte für Wirtschaftsflächen. Herausforderungen und Trends am Beispiel des Stadtentwicklungsplanes Wirtschaft in Berlin [New concepts for economic areas. Challenges and trends using the case of the urban development plan for economy in Berlin] (Vol. 4). German Institute of Urban Affairs.

Werner-von-Siemens Centre for Industry and Science e.V. (2021). Industrie- und Wissenschaftscampus [Industry and knowledge campus]. https://wvsc.berlin

WISTA Management. (2020a). Jahresbericht 2019 [Annual report 2019].

WISTA Management. (2020b). WISTA erhält Mandat vom Senat für schnelle Entwicklung landeseigener Flächenpotenziale [WISTA receives mandate from Senate for faster development of land potentials]. https://www.wista.de/aktuelles/news/wista-erhaeltmandat-vom-senat-fuer-schnelle-entwicklunglandeseigener-flaechenpotenziale

Zukunft Berlin-Ideen aus der Metropole. Folge 1: Berlin als Vorreiter für Innovationen [Future Berlin-Ideas from the metropolis. Episode 1: Berlin as pioneer for innovation]. (2020, September 5). Zukunftsorte Berlin. https://zukunftsorte.berlin/downloads

Zukunft Berlin-Ideen aus der Metropole. Folge 2. Kooperation aus Wirtschaft und Wissenschaft [Future Berlin-Ideas from the metropolis. Episode 2: Cooperation from economy and science]. (2020, September 12). Zukunftsorte Berlin. https://zukunftsorte. berlin/downloads

Zukunft Berlin-Ideen aus der Metropole. Folge 3: Zukunftsjobs und das Werben um Talente [Future BerlinIdeas from the metropolis. Episode 3: Future jobs and the recruitment of talents]. (2020, September 19). Zukunftsorte Berlin. https://zukunftsorte. berlin/downloads

\section{About the Authors}

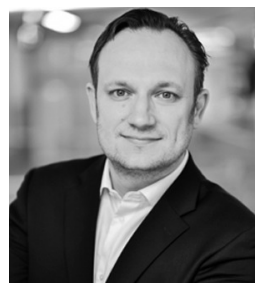

Lech Suwala is a professor in Urban and Regional Economics at Technical University of Berlin and research associate within the working group of Economic Geography at the Humboldt University of Berlin. His research interests encompass spatial structural change from a creativity, innovation and entrepreneurship perspective, regional economic policies, European and regional planning, management geography, geography of the firm, family firms as well as development path trajectories of firms and regions. 


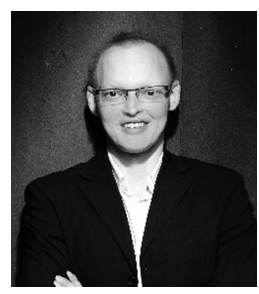

Robert Kitzmann is a research associate and post-doctoral researcher within the working group of Economic Geography at the Humboldt-University of Berlin. His research topics encompass housing market development, housing ownership and housing policies. Furthermore, he is interested in urban and neighborhood transition as well as the influence of housing on neighborhood development. His regional focus is Berlin as well as the US-American context.

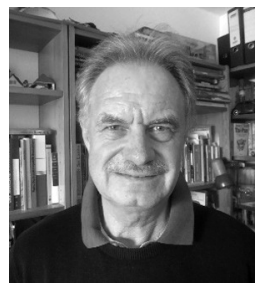

Elmar Kulke is a professor of Economic Geography at the Humboldt University of Berlin. His research topics are structural and locational change of retailing, geographies of the Global South, e.g., internationalization of services and commodity chains for fresh food and vegetables, connecting production in the Global South and retailing in the Global North as well as regional economic policies in Berlin. Regional research areas are Germany and the Global South. 